\title{
Eficácia do programa de remediação auditivo-visual computadorizado em escolares com dislexia***
}

\author{
Efficacy of an audio-visual computerized remediation program in \\ students with dyslexia
}

Giseli Donadon Germano*

Simone Aparecida Capellini**

\begin{abstract}
*Fonoaudióloga. Doutora em Educação pela Faculdade de Filosofia e Ciências da Universidade Estadual Paulista Marília - São Paulo. Endereço para correspondência: Rua Frei Jacinto, 267 - Marília - São Paulo - CEP 17501-240 (giseliger@yahoo.com.br).

**Fonoaudióloga. Doutora em Ciências Médicas pela Faculdade de Ciências Médicas da Universidade Estadual de Campinas. Docente do Departamento de Fonoaudiologia da Faculdade de Filosofia e Ciências da Universidade Estadual Paulista Marília - São Paulo.

***Trabalho Realizado no Centro de Estudos da Educação e Saúde da Faculdade de Filosofia e Ciências da Universidade Estadual Paulista Marília - São Paulo - Apoio da Coordenação de Aperfeiçoamento de Pessoal de Nível Superior.
\end{abstract}

Artigo Original de Pesquisa Artigo Submetido a Avaliação por Pares Conflito de Interesse: não

Recebido em 10.04.2008. Revisado em 24.06.2008; 06.10.2008. Aceito para Publicação em xx.xx.xxxx.

\begin{abstract}
Background: an audio-visual computerized remediation program in students with developmental dyslexia. Aim: to verify the efficacy of an audio-visual computerized remediation program in students with developmental dyslexia. The specific goals of this study involved the comparison of the linguisticcognitive performance of students with developmental dyslexia with that of students considered good readers; to compare the results obtained in pre and post-testing situations of students with dyslexia who were and were not submitted to the program; and to compare the results obtained with the remediation program in students with developmental dyslexia to those obtained in good readers. Method: the participants of this study were 20 students who were divided as follows: group I (GI) subdivided in: GIe (five students with developmental dyslexia who were submitted to the program) and GIc (five students with developmental dyslexia who were not submitted to the program); group II (GII) was subdivided in: GIIe (five good readers who were submitted to the program) and GIIc (five good readers who were not submitted to the program). An audio-visual computerized remediation program was used - "Play on". Results: results indicate that GI presented a lower performance in auditory processing and phonological awareness when compared to GII in the pre-testing situation. However, GIe presented a similar performance to that of GII in the posttesting situation, indicating the effectiveness of the audio-visual remediation program in students with developmental dyslexia. Conclusion: this study made evident the effectiveness of an audio-visual remediation program in students with developmental dyslexia.
\end{abstract}

Key Words: Dyslexia; Intervention; Learning.

\section{Resumo}

Tema: programa de remediação auditivo-visual computadorizado em escolares com dislexia do desenvolvimento. Objetivos: verificar a eficácia de um programa de remediação auditivo-visual computadorizado em escolares com dislexia do desenvolvimento. Dentre os objetivos específicos, o estudo teve como finalidade comparar o desempenho cognitivo-lingǘstico de escolares com dislexia do desenvolvimento com escolares bons leitores; comparar os achados dos procedimentos de avaliação de pré e pós testagem em escolares com dislexia submetidos e não submetidos ao programa; e, por fim, comparar os achados do programa de remediação em escolares com dislexia e escolares bons leitores submetidos ao programa de remediação. Método: participaram deste estudo 20 escolares, sendo o grupo I (GI) subdivido em: GIe, composto de cinco escolares com dislexia do desenvolvimento submetidos ao programa, e GIc, composto de cinco escolares com dislexia do desenvolvimento não submetidos ao programa. O grupo II (GII) foi subdividido em GIIe, composto de cinco escolares bons leitores submetidos à remediação, e GIIc, composto de cinco escolares bons leitores não submetidos à remediação. Foi realizado o programa de remediação auditivo-visual computadorizado Play-on. Resultados: os resultados deste estudo revelaram que o GI apresentou desempenho inferior em habilidade de processamento auditivo e de consciência fonológica em comparação com o GII em situação de pré-testagem. Entretanto, o GIe apresentou desempenho semelhante ao GII em situação de pós-testagem, evidenciando a eficácia da remediação auditivo-visual em escolares com dislexia do desenvolvimento. Conclusão: o estudo evidenciou a eficácia do programa de remediação auditivo-visual em escolares com dislexia do desenvolvimento. Palavras-Chave: Dislexia; Intervenção; Aprendizagem.

Referenciar este material como:

A Germano GD, Capellini SA. Efficacy of an audio-visual computerized remediation program in students with dyslexia (original title: Eficácia do programa de Z remediação auditivo-visual computadorizado em escolares com dislexia). Pró-Fono Revista de Atualização Científica. 2008 out-dez;20(4):237-42. 


\section{Introduction}

Dyslexia is a specific learning disorder of neurological origin, characterized by the difficulty with the correct fluency in reading and the difficulty in decoding and spelling skills, resulting of a deficit in the phonological component of the language1. Because of the phonological deficit, some of the phonological awareness training programs have been shown to be effective to improve the phonological letter-sound conversion skills, damaged in individuals with dyslexia. There are few national studies on the theme. The studies to verify the effectiveness of a phonological remediation program in students with specific learning disorder and learning disabilities concluded that there was an improvement in the phonological processing of information, which improved the emergence of syntactic phonological awareness2-3.

However, the international literature shows more remediation studies with students with developmental dyslexia, with emphasis on training the phonological awareness in students with dyslexia. The results indicated that the training of phonological awareness has lasting effects, and that it was possible to observe these effects specially in the improvement of their reading comprehension4-13. Some recent studies used computer programs with tasks of phonological awareness (phonemic discrimination, manipulation of phonemes), and the results indicated that the training provided audiovisual improvement of the phonological skills of dyslexic students14-15.

Based on what was exposed above, this study aimed to verify the effectiveness of an auditoryvisual computerized remediation program in students with developmental dyslexia. Among the specific objectives, the study intended to compare the cognitive-language performance of students with developmental dyslexia with good readers; compare the findings of the procedures used in the evaluation of pre and post-testing in students with dyslexia submitted and not submitted to the program, and compare the findings of the phonological remediation program in students with dyslexia and good readers submitted to the remediation program.

\section{Method}

This study was approved by the Committee on Ethics in Research, of the Faculty of Philosophy and Science - FFC/UNESP - Marilia - São Paulo, under the protocol number 3118/2006.
A group of 20 schoolchildren in the second to fourth grades of an elementary school of the City of Marilia - São Paulo, both genders, with an age range between eight and twelve years.

The students with developmental dyslexia were submitted to

phonological assessment at the Centre of Study of Education and Health (CEES/UNESP- Marília - São Paulo - Brazil) and to an interdisciplinary evaluation at the the Ambulatory of Child Neurology of the Clinical Hospital of State University of São Paulo FM/UNESP -Botucatu - São Paulo - Brazil).

The subjects were considered dyslexic when presented the following criteria in the interdisciplinary assessment: static balance; appendicular coordination; motor persistence, dynamic balance, torso-limb coordination and sensitivity alteration in the neurological evaluation, normal cognitive level and discrepancy between verbal intellectual quotient and performance intellectual quotient in the psychological assessment WISC III-R, memory, reading and writing alteration in the neuropsychological battery, phonemic, syllabic, rhyme and alliteration alteration in the phonological awareness test, reading level and reading speed lower to age and school level, phonological disorder in the phonological assessment, single word and non-word reading and writing, thematic essay, and partial comprehension of text reading.

The following were adopted as exclusion criteria: the non-submission of the Term of Free and Informed Consent, students with an interdisciplinary diagnosis of Learning disabilities or who presented eyesight, hearing and cognitive performance below normal standards, and / or other genetic or neurological syndromes. The students were divided into two groups:

1. Group I (GI): Group composed by ten (100\%) students with interdisciplinary diagnosis of developmental dyslexia of both genders, with an average age of ten years and three months subdivided into:

. group Ie (GIE): composed by five (100\%) students with developmental dyslexia, which were submitted to the thirteen sessions of the phonological remediation program, one $(20 \%)$ from the second grade, one $(20 \%)$ from the third grade, and three $(60 \%)$ from thefourth grade, with $20 \%$ of females and $80 \%$ of males;

. group IC (GIC): composed of five (100\%) students with developmental dyslexia, one (20\%) from the second grade, one (20\%) from the third grade, and 
three $(60 \%)$ in the fourth grade, with $20 \%$ of females and $80 \%$ of males who were not submitted to the thirteen sessions of the program of remediation with reading.

2. Group II (GII): composed by ten $(100 \%)$ good readers, of both genders, with an average age of ten years and three months, matched according to gender, education and age with the GI, subdivided into:

. group IIe (GIIe): composed by five good readers submitted to the thirteen sessions of the phonological remediation program

- group IIc (GIIc): composed by five good readers who were not submitted to the phonological remediation program.

Students who were considered good readers were those who have obtained satisfactory performance in teaching evaluations related to knowledge and word recognition and text comprehension by two consecutive bimesters indicated by the teachers of the second to fourth grades from a public school of Marilia-Sao Paulo. The parameter used by the teacher was the performance in reading of the student as compared to group-class.

The students of both groups were first submitted to the procedures of

Pre-test, conducted at the Centre of Study of Education and Health (CEES/UNESP- Marília - São Paulo - Brazil). The procedures for pre and post test included Evaluation of the auditory processing, with dichotic and verbal tests (dichotic of digit and alternate byssilabes test) 16 and phonological awareness - sequential evaluation instrument Confias17.

As a procedure for remediation, it was used the Play-on software - Jeu d'entraînement à la lecture, in groups GIe and GIIe and adapted to the Brazilian Portuguese18. The program was chosen because it is based on listening skills that foster the hearing perception of grapheme-phoneme conversion, necessary for learning the alphabetic writing system of the Portuguese language, being granted permission to use the program by the authors for this research. The phonemes worked were established according to the order of development of speech and language (/b/, /p/, /t/, /d/, /k/, /g/, /f/, /v/, /s/, /z/, //, / /, /l/, /r/). The activities of the program included discrimination of phonemes in logatomos, words and phrases, deletion of phonemes in logatomos, dissyllabic and trisyllabic words. The program was conducted in 13 sessions, lasting for 40 minutes with each child individually, twice a week.
The results were analyzed statistically, and adopted the significance level of 5\% (0005) for the application of statistical tests $(*)$. For the implementation of statistical analysis, SPSS (Statistical Package for Social Sciences) was used in its version 13.0 , to obtain the results, by using the MannWhitney test and Posts of placarded Wilcoxon.

\section{Results}

The results showed improvement in performance of the remedied students when compared (GIE and GIIe) in pre and post-testing in the dichotic digits tests and disyllabic alternated test, as shown in Table 1.

In the intragroup comparison for the Phonological Awareness procedure - CONFIAS, it was found that there was statistical significant difference in the Post-testing situation between the GIe and GIc in subtests of identification of initial syllable, identification of medial syllable, syllabic transposition, phonemic synthesis, phonemic segmentation, production of rhyme, and phonemic exclusion and phonemic transposition (Table 2).

There were also statistically significant difference at the post-testing between GIe and GIc in the total score of phonemic skills, showing an improvement in

GIe performance when compared to the GIc. Also, the students without learning difficulties had difficulty in implementing these subtests, suggesting a lack of dominance in the use of the phonological awareness abilities.

It was also noticed that the performance of students with dyslexia (GI) was lower than the performance of the good readers (GII) showing the improvement in the performance of GIe in the posttesting situation and the effectiveness of the remediation program.

There was statistically significant difference when comparing the pre and post-testing of GIE of GIC at the phonemic level, showing an increase of the average score of the GIE in post-testing, suggesting the effectiveness of the program for remediation

There was also a statistically significant difference in the phonemic level between GIIe and GIIc when pre and post tests were compared, indicating

improvement in the performance of GIIe after being submitted to the remediation program. There was also statistical significant difference in the comparison between the groups of dyslexic (GI) and good readers (GII) in the phonemic and syllabic 
level in pre and post testing, indicating that the performance of $\mathrm{GI}$ is

below GII, indicating the presence of the phonological deficit in GI and the effectiveness of the remediation program in post-testing.

During the implementation of the phonological remediation program it was observed that the students showed lower performance in the sessions of

discrimination of pairs of phonemes in logatomes (/t/ and /d/, /k/ and /g/ and /f/ and /v/), in words $(/ \mathrm{t} /$ and $/ \mathrm{d} / / \mathrm{f} /$ and $/ \mathrm{v} /)$, and in phrases $(/ \mathrm{b} /$ and $/ \mathrm{p} /$ and $/ \mathrm{k} /$ and $/ \mathrm{g} /)$.
However, in the deletion task, it was observed that the students had lower performance in the sessions of deletion of phonemes in the trisyllabic $/ \mathrm{J}, /$ I I It was noticed that the performance of the good readers (GIIe) is higher than that of students with developmental dyslexia (GIE) in deletion and discrimination tasks, as can be observed in Figure 1 .

TABLE 1. Inter-group comparison of the students from GIe, GIc, GIIe and GIIc in dichotic digits test and SSW with the Mann-

Whitney test.

\begin{tabular}{|c|c|c|c|c|c|c|c|c|}
\hline \multirow{3}{*}{ Variable } & \multicolumn{8}{|l|}{ Groups } \\
\hline & \multicolumn{2}{|c|}{ GIE x GIC } & \multicolumn{2}{|c|}{ GIIE x GIIC } & \multicolumn{2}{|c|}{ GIE X GIIE } & \multicolumn{2}{|c|}{ GIC x GIIC } \\
\hline & DD & SSW & DD & SSW & DD & SSW & DD & SSW \\
\hline RE_PRE & 0,387 & 0,576 & 0,749 & $0,005^{*}$ & $0,016^{*}$ & $0,008^{*}$ & $0,012^{*}$ & $0,003^{*}$ \\
\hline RE_POS & 0,156 & $0,005^{*}$ & 0,749 & $0,005^{*}$ & 0,287 & 0,059 & $0,009 *$ & $0,003^{*}$ \\
\hline LE_PRE & $0,009 *$ & 0,577 & $>0,999$ & $0,005^{*}$ & $0,028^{*}$ & $0,036^{*}$ & 0,101 & $0,003^{*}$ \\
\hline LE_POS & 0,517 & $0,005^{*}$ & 0,828 & $0,005^{*}$ & 0,209 & 0,105 & $0,026^{*}$ & $0,003^{*}$ \\
\hline classifi_PRE & $>0,999$ & 0,571 & 0,317 & $0,005^{*}$ & $0,014 *$ & $0,020^{*}$ & $0,003^{*}$ & $>0,999$ \\
\hline classifi_POS & $0,014 *$ & $0,005^{*}$ & $>0,999$ & $0,003 *$ & 0,317 & 0,134 & $0,003 *$ & $>0,999$ \\
\hline
\end{tabular}

Caption: $\mathrm{DD}=$ dichotic of digits, $\mathrm{SSW}$ = rotated disyllabic, $\mathrm{RE}$ = right ear, $\mathrm{LE}=$ left ear. 
TABLE 2. Intra-group comparison of students from GIE, GIC, GIIe and GIIc in the assessment of phonological awareness (CONFIAS).

\begin{tabular}{|c|c|c|c|c|}
\hline \multirow{2}{*}{ Variáble } & \multicolumn{4}{|l|}{ Groups } \\
\hline & GIE x GIC & GIIE x GIIC & GIE X GIIE & GIC x GIIC \\
\hline SLPre & 0,396 & 0,059 & $0,008^{*}$ & $0,017 *$ \\
\hline SLPos & 0,515 & 0,571 & 0,154 & 0,054 \\
\hline PLPre & 0,459 & $0,006^{*}$ & $0,008 *$ & $0,006^{*}$ \\
\hline PLPos & $0,008^{*}$ & $0,005^{*}$ & 0,461 & $0,005^{*}$ \\
\hline Tpre & $0,034^{*}$ & 0,092 & 0,452 & $0,005^{*}$ \\
\hline TPos & 0,242 & 0,136 & 0,831 & $0,005 *$ \\
\hline CLPre & 0,419 & $>0,999$ & 0,053 & 0,134 \\
\hline CLPos & 0,134 & $>0,999$ & $>0,999$ & 0,134 \\
\hline
\end{tabular}

Caption: $\mathrm{NC}=$ phonemic level, $\mathrm{NS}=$ syllabic level, $\mathrm{CL}=$ classification $)$. phrases $(\mathrm{F})$.

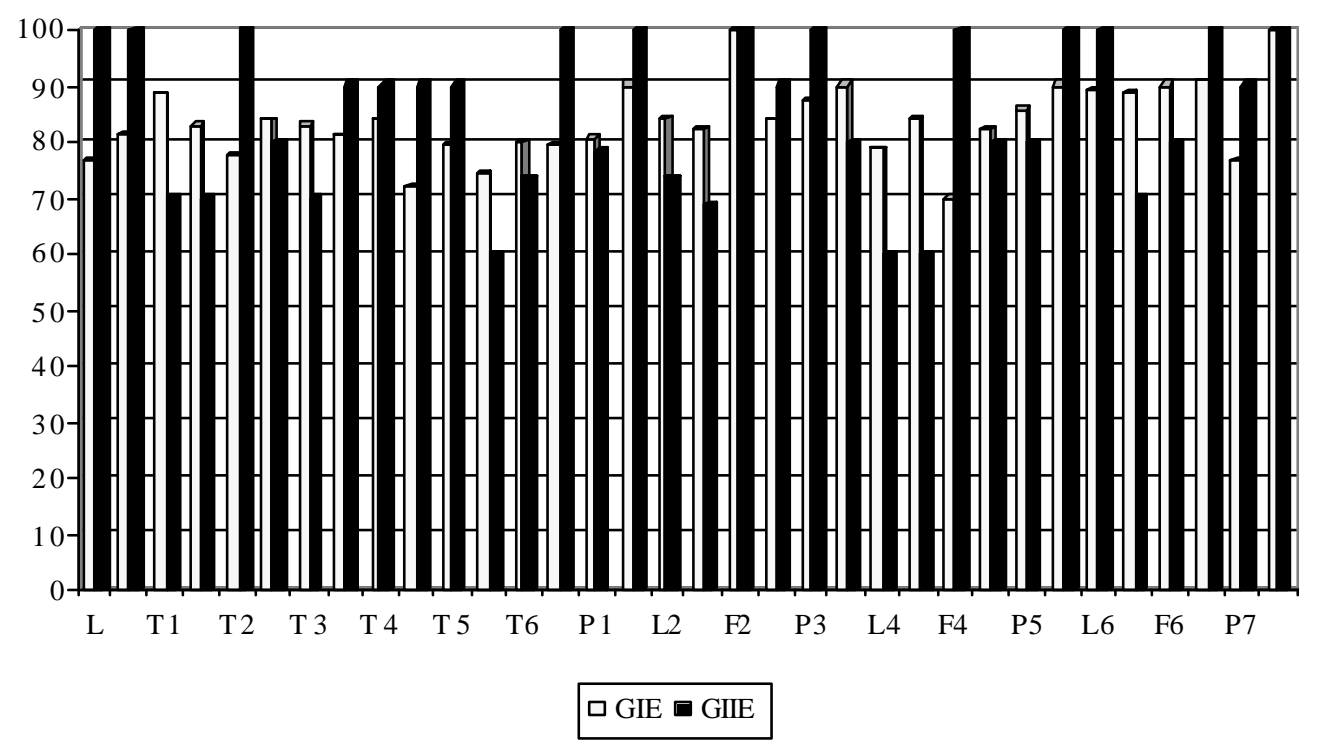




\section{Discussion}

The results of this study revealed the difficulty in integration of the information found in tests of dichotic digits and dissyllabics alternated in pre-testing situation, because the average achieved by the students with developmental dyslexia was lower than that of students without learning difficulties. There was statistically significant difference in the performance of GIe and GIIe when compared in pre and post-testing situations in the right ear and left ear, indicating better performance of students of GIIe when compared to GIE. However, students with dyslexia submitted to the remediation program improved when compared in the pre and post tests. The central difficulty of dyslexia is related to sound processing, known as phonological processing. It is also in the difficulties in processing brief and fast hearing clues, implying the lack of ability to understand critical elements of the speech accurately, not allowing, in such a way, access to phonological coding $4,14,19$. The results of this study suggest that children with developmental dyslexia have changes in auditory processing, that is, alteration of the manipulation and use of sound signals, changing since the detection of the sound until the analysis of linguistic information10-15, 19-24. Regarding the evidence of phonological awareness, it was found that students with developmental dyslexia had lower average score than good readers. Besides, both groups had better performance in tests of syllabic skills than phonemic skills. Among the students submitted to the remediation program, there was improvement in the performance of syllabic skills and, mainly, the phonemic one, demonstrating the effectiveness of the remediation program.

Through analysis of the findings, the auditory-visual remediation program caused improvement in activities of reading and writing, phonological awareness and auditory processing. The students with developmental dyslexia have improved by the use of the auditory-visual remediation program, because it gives clear instructions and it is easy to manipulate, for the students which could not perceive the auditory information, using

the visual information to the perception of logatomos and words. The program provided a significant gain of phonological skills in the students with developmental dyslexia, and also in the students without learning difficulties.

This program is easy to manipulate for researchers and also for the school

participants, who felt happy to carry out activities on the computer. The use of games and computer has improved the sustaining of attention time

of the children to the conduction of the activities. The fact that the program led to the improvement of listening and phonological skills shows that this program can be used not only by speech therapists but also in the school environment.

The group of good readers also showed improvement in their performance

when compared in pre and post testing, showing that the abilities of

phonological awareness have not been fully acquired during literacy. Studies have indicated that the phonemic awareness is developed as a result of literacy, around six or seven years old25-28.

It appears that the alphabetic system, regardless of language, does not directly represent the meaning of words, but the sequences of its sounds, that is, a phonological sequence or more specifically, phonemes. Thus, this instruction should occur in the initial period of literacy.

Some authors29-30 yet reported that the opportunity to access the direct instruction of phonemic awareness is not available in $25 \%$ of students in the first grade of fundamental education of middle-class and could cause difficulties in learning and writing code of reading. In this way, it was observed that both students with developmental dyslexia and good readers failed in the

development of transposition, synthesis, segmentation phonemic skills and rhymes.

\section{Conclusion}

The findings of this study enabled us to conclude that:

. the students with developmental dyslexia had lower performance when compared to good readers in the abilities of auditory processing and phonological awareness;

. the students with developmental dyslexia submitted to the remediation program showed improvement in their performance in post-tests when compared to the performance of students with developmental dyslexia not

submitted the remediation program;

. the good readers submitted to the remediation program showed improvement in skills of auditory processing and phonological awareness, demonstrating the need for formal instruction in metalinguistic skills during the literacy, due to the alphabetical basis of Brazilian Portuguese;

. the auditory-visual remediation program Play-on was effective because of the improvement of auditory and phonological skills of the students with developmental dyslexia and also for the good readers. 


\section{References}

1. Lyon GR, Shaywitz SE, Shaywitz BA. Defining dyslexia, comorbidity, teacher's knowledge of language and reading. Ann Dyslexia. 2003; 53: 1-14.

2. Capellini SA. Eficácia do programa de remediação fonológica em escolares com distúrbio específico de leitura e distúrbio de aprendizagem. [Tese]. Campinas (SP): Universidade Estadual de Campinas; 2001.

3. Salgado CA. Programa de remediação fonológica em escolares com dislexia do desenvolvimento. [Dissertação]. Campinas (SP): Universidade Estadual de Campinas; 2005.

4. Kujala T, Karma K, Ceponiene R, Belitz S, Turkkilla P, Tervaniemi $\mathrm{M}$, et al. Plastic neural changes and reading improvement caused by audiovisual training in readingimpaired children. PNAS. 2001 Ago 98(18):10509-14.

5. Richards TL, Berninger VW, Aylward EH, Richards AL, Thomson JB, Nagy WE, et al. Reproducibility of proton MR spectroscopic imaging (PEPSI): comparison of dyslexic and normal-reading children and effects of treatment on brain lactate levels during language tasks. Am J Neuroradiol. 2002 Nov-Dec; 23 (10): 1678-85.

6. Hayes EA, Warrier CM, Nicol TG, Zecker SG, Kraus N. Neural plasticity following auditory training in children with learning problems. Clin Neurophs. 2003; 114 (4): 673-48.

7. Elbro C, Petersen DK. Long-term effects of phoneme awareness and letter sound training: an intervention study with children at risk for dyslexia. J. Educ. Psyc. 2004;96(4):660-70.

8. Russo NM, Nicol TG, Zecker SG, Hayes EA, Kraus N. Auditory training improves neural timing in the human brainstem. Beh. Brain Res. 2005; 156 (1): 95-103.

9. Cohen W, Hodson A, O’hare A, Boyle J, Durrani T, McCartney E, et al. Effects of computer-based intervention through acoustically modified speech (Fast for Word) in severe mixed receptive-expressive language impairment: outcomes from a randomized controlled trial. J Speech Lang Hear Res. 2005 Jun (48):715-29.

10. Moore DR, Rosenberg JF, Coleman JS. Discrimination training of phonemic contrasts enhances phonological processing in mainstream school children. Brain Lang. 2005 jan; 94 (1): 72-85.

11. Brambati SM, Termine C, Ruffino M, Danna M, Lanzi G, Stella G, et al. Neuropsychological deficits and neural disfuncion in familial dislexia. Brain Res. 2006;(1113):17485 .

12. Strehlow U, Haffner J, Bischof J, Gratzka V, Parzer P, Resch F. Does successful training of temporal processing of sound and phoneme stimuli improve reading and spelling? Eur. Child Adolesc. Psychiatry, 2006; 1113(1): 174-85.

13. Regtvoort AGFM, Leij A. Early intervention with children of dyslexic parents: effects of computer-based reading instruction at home on literacy acquisition. Lear. Ind. Differences. 2007; 17 (4): 35-53.

14. Temple E, Deutsch GK, Poldrack RA, Miller S, Tallal $\mathrm{P}$, Merzenich MM, et al. Neural deficits in children with dyslexia ameliorated by behavioral remediation: evidence from functional MRI. PNAS. 2003 Mar 100(5):2860-5.
15. Magnan A, Ecalle J. Audio-training in children with reading disabilities. Comp. Educ. 2006; 46 (4): 407-25.

16. Pereira LD, Schochat E. Processamento Auditivo Central: manual de avaliação. São Paulo: Lovise, 1997.

17. Moojen S, Lamprecht R, Santos RM, Freitas GM, Brodacz R, Siqueira M, et al. Consciência fonológica: Instrumento de avaliação seqüencial. São Paulo: Casa do Psicólogo; 2003.

18. Germano GD. Eficácia do programa de remediação fonológica Play On em crianças com dislexia do desenvolvimento. [Dissertação] Marilia (SP): Universidade Estadual Paulista; 2008.

19. Booth JR, Burman DD, Meyer JR, Gitelman DR, Parrish TB, Mesulam MM. Development of brain mechanism for processing orthographic and phonologic representation. J. Cogn. Neurosc. 2004 Sept 16(7):1234-49.

20. Moore DR. Auditory processing disorder (ADP) Potential contribution of mouse research. Brain res. 2006; 1091 (1): 200-6.

21. Parmentier FBR, Maybery MT, Huitson M, Jones DM. The perceptual determinants of repetition learning auditory space. J. Mem. Lang. 2008. Available from ww w.elsevier.com/locate/jmldoi:10.1016/ j.jml.2008.02.001.

22. Agnew JA, Dorn C, Eden GF. Effect of intensive training on auditory processing and reading skills. Brain Lang. 2004; 88 (1): 21-5.

23. Boets $\mathrm{B}$, Wounters $\mathrm{J}$, Wieringen $\mathrm{A}$, Ghesquière $\mathrm{P}$. Auditory processing, speech perception and phonological ability in pre-school children at high-risk for dyslexia: a longitudinal study of the auditory temporal processing theory. Neuropsy. 2007; 45 (8): 1608-20.

24. Waber DP, Weiter MD, Wolff PH, Marcus DJ, Ariel R, Forbes $\mathrm{P}$, et al. Processing of rapid auditory stimuli in school-age children referred for evaluation of learning disorders. Child Devel. 2007;71(1):37-49.

25. Morais J. Alphabetic literacy and psychological structure. Letras de Hije. 1998;33(4):61-79.

26. Cielo CA. A avaliação das habilidades em consciência fonológica. J. Bras. Fonoaudiologia. 2003;4(16):163-74.

27. Friedmann N, Lukov L. Developmental surface dyslexias. Córtex. 2008 Available from www.elsevier.com/ locate/cortexdoi:10.1016/j.cortex.2007.09.005.

28. Godoy DMA. O papel da consciência fonológica no processo de alfabetização. Pró-Fono Revista de Atualização Científica. 2003;15(3):241-50

29. Paula GR, Mota HB, Keske-Soares MA. A terapia em consciência fonológica no processo de alfabetização. Prófono Revista de Atualização Científica. 2005,17(2):175-84.

30. Lamprecht RR (org) Aquisição fonológica do português: perfil de desenvolvimento e subsídios para a terapia. Porto Alegre: Artmed; 2004. 